\title{
High $\mathrm{N}_{2} \mathrm{O}$ variations induced by agricultural practices in integrated weed management systems
}

\author{
Anthony Vermue ${ }^{1,3} \cdot$ Bernard Nicolardot $^{1,4}$ - Catherine Hénault ${ }^{2}$
}

Accepted: 11 July 2016 / Published online: 2 August 2016

(C) INRA and Springer-Verlag France 2016

\begin{abstract}
Integrated weed management aims to decrease the dependence of cropping systems on herbicides by using a combination of several agricultural practices. Environmental impacts of individual practices under various conditions are already known. However, there is scarce knowledge on the impact of combining several practices. Therefore, we studied $\mathrm{N}_{2} \mathrm{O}$ emissions of weed management cropping systems that use differing practices such as crop diversity, tillage, and herbicide pressure, during about 1 year. Data were compared with a conventionally managed cropping system. Results were also simulated using the NOE model. Results show a large variation of $\mathrm{N}_{2} \mathrm{O}$ emissions, ranging from $177 \mathrm{~g} \mathrm{~N}_{2} \mathrm{O}-\mathrm{N} / \mathrm{ha}$ for intensive tillage integrated weed management to $362 \mathrm{~g} \mathrm{~N}_{2} \mathrm{O}$ $\mathrm{N} / \mathrm{ha}$ for the conventional cropping system, $777 \mathrm{~g} \mathrm{~N} 2 \mathrm{O}-\mathrm{N} / \mathrm{ha}$ for the no herbicide cropping system and $5226 \mathrm{~g} \mathrm{~N}_{2} \mathrm{O}-\mathrm{N} / \mathrm{ha}$ for no-till integrated weed management. Most $\mathrm{N}_{2} \mathrm{O}$ emissions occurred in spring, despite the absence of fertilizing related $\mathrm{N}_{2} \mathrm{O}$ peaks. The lowest emissions occurred in autumn and winter. Emissions are explained by interactions between specific soil potential denitrification rate, soil bulk density,
\end{abstract}

Bernard Nicolardot

bernard.nicolardot@agrosupdijon.fr

1 Agroécologie, AgroSup Dijon, CNRS, INRA, Univ. Bourgogne Franche-Comté, 21000 Dijon, France

2 INRA, UR 0272, Unité de Recherche en Science du Sol, 2163 Avenue de la Pomme de Pin, CS 40001 Ardon, 45075 Orléans cedex 2, France

3 Present address: INRA, UMR 1248 AGIR, Auzeville BP 52627, 31326 Castanet-Tolosan cedex, France

4 AgroSup Dijon, UMR 1347 Agroécologie, 26 Bd Docteur Petitjean, BP 87999, 21079 Dijon Cedex, France temperature, soil water, and inorganic $\mathrm{N}$ contents. $\mathrm{N}_{2} \mathrm{O}$ emissions are accurately predicted by the model NOE, with a global Nash-Sutcliffe coefficient of efficiency equal to 0.80 .

Keywords Nitrous oxide $\cdot$ High-resolution measurements · Modeling $\cdot$ NOE model $\cdot$ Integrated weed management . Cropping systems $\cdot$ Tillage

\section{Introduction}

With the increase in food needs and environmental concerns, agriculture is currently facing new challenges (Foley et al. 2011) requiring the development of more sustainable cropping systems (Reganold et al. 2001).

Integrated weed management aims to lower reliance on herbicides in cropping systems (Chikowo et al. 2009) with limited economic and social impacts (Pardo et al. 2010), while introducing new combinations of agricultural practices in the development of these systems. These combinations may differ greatly from one system to another and include a large variety of practices, such as false seed beds, late sowing, mechanical weeding, reduced tillage, specific crop rotations that alternate spring and winter crops, the choice of crop varieties, and the use of pesticides with low ecotoxic impacts (Zoschke and Quadranti 2002). However, in the framework of developing more sustainable agriculture, the performance of systems is not only evaluated as a function of agronomical, economic, and social criteria but also as a function of environmental criteria. When several agricultural practices are implemented, they are likely to alter soil biogeochemical cycles (Chèneby et al. 2009) and different components of the greenhouse gas budget (balance between carbon sequestration and greenhouse gas emissions). Crop rotations are also reported to potentially affect $\mathrm{N}_{2} \mathrm{O}$ emissions from soils (Vilain et al. 2010), as are the 
dates of application and levels of nitrogen fertilization inputs (Van Groenigen et al. 2010). $\mathrm{N}_{2} \mathrm{O}$ emissions from soils are the result of complex interactions between the structure and functioning of microbial communities, as well as soil conditions affected by climatic conditions and land use (Weitz et al. 2001). The variety of pedoclimatic contexts and combinations of soil agricultural practices make their impacts on $\mathrm{N}_{2} \mathrm{O}$ emissions difficult to study in croplands (Hénault et al. 2012). Soil management practices have been reported to affect $\mathrm{N}_{2} \mathrm{O}$ emissions, especially no-till systems which are widely promoted for carbon sequestration purposes (Rochette 2008). Nevertheless, due to considerable $\mathrm{N}_{2} \mathrm{O}$ emission during the first years following a no-till conversion, the benefits for mitigating global warming apparently occur only in the long term (Six et al. 2004).

In combination with the field measurement of $\mathrm{N}_{2} \mathrm{O}$ fluxes and environmental parameters, models can provide better understanding of the mechanisms of $\mathrm{N}_{2} \mathrm{O}$ emissions in soils and estimate the $\mathrm{N}_{2} \mathrm{O}$ budgets of cropping systems. The comparison between measured and simulated fluxes can help to analyze the impacts of each soil variable and the effects of different types of agricultural management (Gabrielle et al. 2006). This approach requires using adequate statistical indicators to assess both the association of and the coincidence between simulated and observed $\mathrm{N}_{2} \mathrm{O}$ emissions (Smith et al. 1996).

The environmental impacts of integrated weed management cropping systems were the subject of global studies using, for example, life cycle analysis (Deytieux et al. 2012), but specific impacts on soil, atmosphere, and water compartments were not assessed experimentally. Thus, our main objective was to contribute to the environmental evaluation of integrated weed management cropping systems by measuring the greenhouse gas emissions emitted from these systems. The specific objectives of this study are (i) to evaluate and compare the $\mathrm{N}_{2} \mathrm{O}$ fluxes emitted from soil for 1 year for four cropping systems (i.e., three integrated weed management systems using different strategies to control weeds and a local conventional system as reference); (ii) to investigate the relationship between $\mathrm{N}_{2} \mathrm{O}$ fluxes, soil parameters, and cropping systems; and (iii) to perform simulations using the NOE model in order to better explain the $\mathrm{N}_{2} \mathrm{O}$ emission patterns observed.

\section{Materials and methods}

\subsection{Experimental site}

The study was conducted at the INRA experimental farm of Dijon-Epoisses, eastern France, $\left(47^{\circ} 20^{\prime} \mathrm{N}, 5^{\circ} 2^{\prime} \mathrm{E}\right)$. The climate was semi-continental, with a mean annual temperature of $10.5{ }^{\circ} \mathrm{C}$ and an average rainfall of $770 \mathrm{~mm}$ year ${ }^{-1}$. The experimental site was set up in 2000 to assess the performance of four cropping systems based on integrated weed management compared to a reference standard system (Chikowo et al. 2009). The original design of the experiment integrated two geographically distant blocks including all the systems, but only one block is electrified at present and therefore used in this study. The surface areas of the four systems investigated were about 1.7 ha each, separated by a grass strip. These systems differed in terms of crop rotations, soil tillage, mechanical and chemical weeding, and crop management.

The first cropping system was the standard reference system (S1) designed to maximize financial returns, with emphasis placed on the use of chemical herbicides for weed control. Moldboard plowing was carried out each year during summer, and herbicides were chosen in accordance with the recommendations of extension services and pesticide producers that must conform to the rules of application defined by ANSES (French Agency of Food, Environmental, and Occupational Health and Safety). The second system (S2) was an integrated weed management system with no-tillage and direct seeding, with a herbicide treatment frequency reduced to $25 \%$ in comparison with S1. The third system (S3) was an integrated weed management system that allows for plowing and other soil tillage operations when necessary, according to field observations, for weed seed bank management. Herbicide treatment frequency for system $\mathrm{S} 3$ was half that of the reference system S1. The last system studied (S5) was a total integrated weed management system with no herbicide treatment. However, in contrast with organic farming, tillage and other pesticide treatments were possible when required. All the systems were studied for 1 year, between March 2012 and March 2013. Crops and cultural operations during the experiment are detailed in Table 1 for each cropping system.

The soil of the experimental site was a Cambisol (Hypereutric) (IUSS Working Group WRB 2006) with a clayey surface layer developed on alluvial deposits. The main mean ( \pm standard deviation) soil characteristics for the four cropping systems were as follows: clay $411 \pm 32 \mathrm{~g} \mathrm{~kg}^{-1}$, silt $534 \pm 32 \mathrm{~g} \mathrm{~kg}^{-1}$, sand $53 \pm 1 \mathrm{~g} \mathrm{~kg}^{-1}, \mathrm{pH} 6.9 \pm 0.1, \mathrm{CaCO}_{3}$ $<1 \mathrm{~g} \mathrm{~kg}^{-1}$, organic C $19.1 \pm 2.4 \mathrm{mg} \mathrm{C} \mathrm{kg}^{-1}$, organic $N$ $1.58 \pm 0.29 \mathrm{mg} \mathrm{N} \mathrm{kg}^{-1}$, cation exchange capacity $21.5 \pm 2.3 \mathrm{cmol}(+) \mathrm{kg}^{-1}$, bulk density $1.49 \pm 0.02 \mathrm{~g} \mathrm{~cm}^{-3}$.

\subsection{Soil physical and chemical parameters}

The inorganic $\mathrm{N}$ contents, bulk densities, temperature, and water contents of the $0-30-\mathrm{cm}$ soil layer were monitored over the experimental period in each plot.

\subsubsection{Soil inorganic $N$ content}

Three soil samples per cropping system were collected randomly each month. Inorganic nitrogen, i.e., $\mathrm{NH}_{4}{ }^{+} \mathrm{N}$ and $\left(\mathrm{NO}_{3}{ }^{-}+\mathrm{NO}_{2}{ }^{-}\right)-\mathrm{N}$, was extracted by shaking $10 \mathrm{~g}$ of moist soil (with measured water content) with $50 \mathrm{~mL}$ 
Table 1 Crops and agricultural operations for the four systems studied from autumn 2011 to spring 2013

\begin{tabular}{|c|c|c|c|c|}
\hline Cropping systems & S1 & $\mathrm{S} 2$ & S3 & S5 \\
\hline Seedling & 12 Oct. 2011 (Winter wheat) & & 24 Oct. 2011 (winter wheat) & \\
\hline Tillage & 9 Sept. 2011 & & & \\
\hline Rolling & 13 Oct. 2011 & 17 Jan. 2012 & & \\
\hline Fertilization & 28 Feb. $2012(50 \mathrm{~N})^{\mathrm{a}}$ & 20 Feb. $2012(108 \mathrm{Mg}, 1083 \mathrm{Ca})$ & 28 Feb. $2012(50 \mathrm{~N})$ & \\
\hline Seedling & & 9 Mar. 2012 (Spring barley) & & 29 Mar. 2012 (Alfalfa) \\
\hline Fertilization & & 9 Mar. 2012 (47 N, 6 P, 7 S) & & \\
\hline Rolling & & 12 Mar. 2012 & & \\
\hline Herbicide $^{\mathrm{b}}$ & 22 Mar. 2012 & 16 Mar. 2012 & 22 Mar. 2012 & \\
\hline Fertilization & 3 Apr. $2012(85$ N) & 17 Apr $2012(84 \mathrm{~N})$ & 2 Apr. $2012(90 \mathrm{~N})$ & 27 Apr. 2012 (42 S, $52.5 \mathrm{Mg})$ \\
\hline Herbicide & & 7 May 2012 & & \\
\hline Fungicide $^{c}$ & 10 May 2012 & & 10 May 2012 & \\
\hline Fertilization & 15 May $2012(30 \mathrm{~N})$ & & 15 May $2012(25 \mathrm{~N})$ & \\
\hline Insecticide $^{\mathrm{d}}$ & 27 May 2012 & & 27 May 2012 & \\
\hline Fungicide $^{c}$ & & 29 May 2012 & & \\
\hline Fertilization & & & & 14 Jun. 2012 (3 S, 2 Mg) \\
\hline Harvest & 18 Jul. 2012 & 25 Jul. 2012 & 24 Jul. 2012 & $\begin{array}{l}\text { 14 Jun. } 2012 \\
\text { 31 Jul. } 2012\end{array}$ \\
\hline Tillage & $\begin{array}{l}\text { 20 Jul. } 2012 \\
\text { 30 Jul. } 2012\end{array}$ & & $\begin{array}{l}26 \text { Jul. } 2012 \\
20 \text { Jul. } 2012\end{array}$ & \\
\hline Seedling & & 1 Aug. 2012 (winter oat) & 1 Aug. 2012 (catch crop) $^{\text {f }}$ & 30 Aug. 2012 (alfalfa) \\
\hline Antislug $^{\mathrm{e}}$ & & 7 Aug. 2012 & & \\
\hline Fertilization & 5 Sept. 2012 (43 P, 47 K) & & & \\
\hline Tillage & $\begin{array}{l}14 \text { Sep. } 2012 \\
1 \text { Oct. } 2012\end{array}$ & & $\begin{array}{l}5 \text { Sep. } 2012 \\
22 \text { Oct. } 2012\end{array}$ & \\
\hline Seedling & 5 Oct. 2012 (winter barley) & & & \\
\hline Cover crushing & & 29 Oct. 2012 & 23 Oct. 2012 & 23 Oct. 2013 \\
\hline Tillage & & & $\begin{array}{l}30 \text { Oct. } 2012 \\
6 \text { Mar. } 2013 \\
8 \text { Apr. } 2013\end{array}$ & $\begin{array}{l}14 \text { Nov. } 2012 \\
6 \text { Apr. } 2013 \\
29 \text { Mar. } 2013 \\
23 \text { Apr. } 2013\end{array}$ \\
\hline Herbicide & 25 Oct. 2012 & & & \\
\hline Antislug $^{\mathrm{e}}$ & 30 Oct. 2012 & & & \\
\hline Fertilizer & 21 Feb. $2013(50 \mathrm{~N})$ & 20 Feb. 2013 (108 Mg, $1083 \mathrm{Ca})$ & & \\
\hline Fertilizer & 29 Mar. $2013(90 \mathrm{~N})$ & & & \\
\hline Herbicide $^{b}$ & 25 Apr. 2013 & 14 May 2013 & & \\
\hline Fongicide $^{c}$ & 6 May 2013 & & & \\
\hline Seedling & & 14 May 2013 (soybean) & 13 May 2013 (soybean) & 25 Apr. 2013 (grain maize) \\
\hline
\end{tabular}

${ }^{\text {a }}$ Kilogram of $\mathrm{N}$ (P, K, S, Mg or Ca) per hectare

${ }^{\mathrm{b}}$ Glyphosate isopropyl amine salt, tribenuron-methyl, mefenpyr-diethyl or metsulfuron-methyl, isoproturon, pendimethaline, prohexadione, mepiquatchoride, ester 1-methylheptyl, or florasulam

${ }^{\mathrm{c}}$ Cyproconazole, bixafen, azoxystrobine, prothioconazole, or fluoxastrobine

${ }^{\mathrm{d}}$ Deltamethrin

${ }^{\mathrm{e}}$ Metaldehyde

${ }^{\mathrm{f}}$ Spring oat, Linse, Niger, Phacelia, and Faba

of a 1-M KCL solution for $1 \mathrm{~h}$. The slurries were then filtered using Whatman No. 42 filter paper (Whatman Group $($ ) , and the extract was collected and frozen $\left(-20{ }^{\circ} \mathrm{C}\right)$. Ammonium and nitrate contents were deter mined by automated colorimetry. The soil gravimetric water content of each subsample was estimated by mass difference before and after an oven-drying period of $24 \mathrm{~h}$ at $105^{\circ} \mathrm{C}$. 


\subsubsection{Soil bulk density}

The bulk density of the soil was measured each spring during the 2 years, 2011-2012 and 2012-2013, in each plot, using steel cylinders of known volumes (10 cm diameter, $5 \mathrm{~cm}$ height). Samples were taken between 0 and $-30 \mathrm{~cm}$ depth, dried at $105^{\circ} \mathrm{C}$ for $24 \mathrm{~h}$, and then weighed. Bulk density $(\rho)$ was calculated as the ratio between the dried soil mass and the volume of the cylinder. Average system bulk density was defined as the mean of three samples taken randomly in the system for each date. Moreover, the estimation of bulk density allowed the calculation of the soil total porosity (P) as per Formula (1):

$\mathrm{P}=1-\rho / \rho_{\mathrm{s}}$

where $\rho$ is the bulk density of the soil and $\rho_{\mathrm{s}}$ is the density of the soil solid particles (2.6).

\subsubsection{Soil temperature, volumetric moisture, and water-filled pore space}

Soil temperature and volumetric moisture were monitored using four thermistor probes (Campbell Scientific $®$ PT100) and four time-domain reflectometer (TDR) site-calibrated probes (Campbell Scientific $\AA$ CS616), respectively, in each plot. Both TDR and temperature probes were set in pairs at two depths $(-5$ and $-20 \mathrm{~cm})$. Temperature and moisture were measured automatically for 5 min every $2 \mathrm{~h}$, every day. The data recorded data were then stored in a CR-1000 (datalogger Campbell Scientific $®)$. A daily average was then calculated as the mean response from the two probes in each layer and plot. The daily proportion of water-filled pore space (WFPS) was calculated afterwards using the following Formula (2):

$\mathrm{WFPS}=\theta / \mathrm{P}$

where $\theta$ is the daily average volumetric water content measured by the TDR probes and $\mathrm{P}$ is the estimated total porosity of the soils.

\section{$2.3 \mathrm{~N}_{2} \mathrm{O}$ emission measurements}

Nitrous oxide $\left(\mathrm{N}_{2} \mathrm{O}\right)$ emissions were measured continuously using the automated chamber method described in Vermue et al. (2013). A specific set of 24 static chambers (length $70 \mathrm{~cm}$, width $70 \mathrm{~cm}$, height $30 \mathrm{~cm}$ ) was set up (Fig. 1). The chambers were placed on each plot (six chambers for each system, i.e., S1, S2, S3, and S5) within a 25-m radius around the analyzing device located on the grass strip to take into account the spatial variability inside each plot as soon as possible. The chambers were present during the entire study period and removed for very short periods when tillage operations were performed. In the field, the chambers were pressed $10 \mathrm{~cm}$ into the soil, giving a 98-L headspace volume. Vegetation was present inside the chambers for the early growth stages of the different crops. Nevertheless, when the crop height was higher than the top of the chamber, the plants were cut to allow measurements. Nitrous oxide $\left(\mathrm{N}_{2} \mathrm{O}\right)$ concentrations in the headspaces were measured by a Megatec $\AA$ IR analyzer $46 \mathrm{i}$ (Thermo Scientific), connected to each chamber using an automated screening system. The evolution of $\mathrm{N}_{2} \mathrm{O}$ concentrations in the headspace of the chamber was recorded over a 20-min period, with a time step of $20 \mathrm{~s}$, four times a day for each chamber. The chambers were automatically re-opened at the end of each kinetic, to ensure the normal fertilization and humidification of the soils by rain. Recorded data were then stored on a CR1000 datalogger (Campbell Scientific () ) and collected once a week. $\mathrm{N}_{2} \mathrm{O}$ fluxes were calculated as the slope of the linear regression between the $\mathrm{N}_{2} \mathrm{O}$ concentrations with the 20 min measurement period expressed in seconds and converted into grams of $\mathrm{N}-\mathrm{N}_{2} \mathrm{O} \mathrm{ha}{ }^{-1}$ day $^{-1}$. The sensitivity threshold, determined from the error on the slope measurements as per the equation defined by Laville et al. (2011), was $0.7 \mathrm{~g} \mathrm{~N}$ $\mathrm{N}_{2} \mathrm{O}$ ha $^{-1}$ day ${ }^{-1}$. Daily $\mathrm{N}_{2} \mathrm{O}$ fluxes were estimated as the means of the $4 \times 6$ replicates calculated each day in each system. Absences of measurements mostly corresponded to periods during which the chambers were removed for technical operations on the fields (e.g., sowing, tillage, harvest). To ensure comparison if measurements were missing in one system, the data in all the remaining systems were excluded. Cumulative $\mathrm{N}_{2} \mathrm{O}$ emissions therefore corresponded to the sum of $\mathrm{N}_{2} \mathrm{O}$ emissions observed over a total of 255 days without extrapolation and during which measurements were available for all the systems simultaneously.

\section{$2.4 \mathrm{~N}_{2} \mathrm{O}$ emission simulations}

$\mathrm{N}_{2} \mathrm{O}$ emissions were simulated with the NOE model (Hénault et al. 2005). NOE is an algorithm which allows simulating $\mathrm{N}_{2} \mathrm{O}$ fluxes at the cropland scale by cumulating both nitrification and denitrification emissions of $\mathrm{N}_{2} \mathrm{O}$ (Formula 3) and taking $\mathrm{N}_{2} \mathrm{O}$ reduction into account. Each subpart of the model relies on the combination between specific soil biological $\left(D_{p}\right.$, $z$, and $r_{\text {max }}$ ) and environmental parameters (soil temperature, WFPS, nitrate and ammonium contents) which were measured in situ (Formulas 4 and 5).

$$
\begin{aligned}
& \mathrm{N}_{2} \mathrm{O}=\left[\mathrm{N}_{2} \mathrm{O}\right]_{\mathrm{denit}}+\left[\mathrm{N}_{2} \mathrm{O}\right]_{n i t} \\
& {\left[\mathrm{~N}_{2} \mathrm{O}\right]_{\mathrm{denit}}=r_{\max } \cdot D_{p} \cdot F_{N} \cdot F_{w} \cdot F_{T}} \\
& {\left[\mathrm{~N}_{2} \mathrm{O}\right]_{n i t}=r_{\max } \cdot z \cdot N_{w} \cdot N_{N H 4} \cdot N_{T}}
\end{aligned}
$$

where $\left[\mathrm{N}_{2} \mathrm{O}\right]_{\text {denit }}$ is the $\mathrm{N}_{2} \mathrm{O}$ produced by denitrification and $\left[\mathrm{N}_{2} \mathrm{O}\right]_{\text {nit }}$ is the $\mathrm{N}_{2} \mathrm{O}$ produced by nitrification, both in 


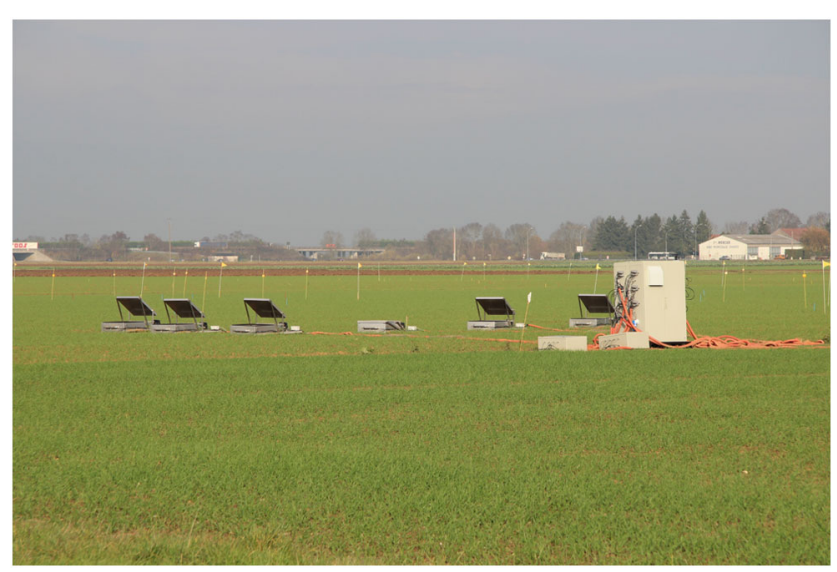

Fig. 1 Partial view of the experimental design equipped with automated static chambers, each of which has a 98-L headspace and equipped with an air temperature sensor and a fan to homogenize the atmosphere during the measurement. The chambers are connected to a waterproof cabinet containing the $\mathrm{N}_{2} \mathrm{O}$ gas analyzer, the datalogger to record soil moisture and temperature, headspace temperature, and data from the analyzer. It also contains the automated screening system that controls the opening and closing of the chambers and starts/stops the fan inside each chamber

kilograms of $\mathrm{N}$ per hectare per day. $r_{\max }$, revealing the capacity of the soil to reduce $\mathrm{N}_{2} \mathrm{O}$, is the maximum ratio of accumulated $\mathrm{N}_{2} \mathrm{O}$ to denitrified nitrate under anaerobic conditions; $D_{p}$ is the potential denitrification rate (also in $\mathrm{kg}$ $\mathrm{N}$ ha ${ }^{-1}$ day $\left.^{-1}\right) ; F_{N}, F_{W}$, and $F_{T}$ are response functions for soil nitrate content, water-filled pore space, and temperature, respectively (Hénault and Germon 2000); $z$ is the proportion of nitrified nitrogen emitted as $\mathrm{N}_{2} \mathrm{O}$; and $N_{w}, N_{N H 4}$, and $N_{T}$ are response functions for soil water content, ammonium content, and temperature, respectively.

NOE has been applied in different areas and climatic contexts (Gabrielle et al. 2006; Hergoualc'h et al. 2009). NOE was used here under the conditions defined in the original publication (Hénault et al. 2005). For each system, the soil potential denitrification rate was measured using eight undisturbed soil cores according to Hénault and Germon (2000), in May 2011. The soil's capacity to reduce $\mathrm{N}_{2} \mathrm{O}$ was estimated on sieved composites of soil according to Henault et al. (2001), in January 2013. The soil nitrification parameters $(z=0.0006)$ used in the simulation were measured previously on a site close to the current experimental site (Hénault et al. 2005). Cumulative simulated $\mathrm{N}_{2} \mathrm{O}$ emissions corresponded to the sum of $\mathrm{N}_{2} \mathrm{O}$ emissions simulated over a total of 163 days without extrapolation. This period corresponded to the number of days during which all the data required to perform the simulation were available for all the systems (e.g., TDR measurements).

\subsection{Statistical analysis}

All analyses were conducted using R (R Core Team 2016). Most of the data acquired during this study did not follow a normal law according to the Shapiro-Wilk test; therefore, only nonparametrical tests were used. All tests were performed with a statistical significance set at 0.05 .

The Kruskal-Wallis test was used to highlight the treatment effect with the null hypothesis that tested that variables were not significantly different between the treatments. Regarding the measured data, Kruskal-Wallis tests were used to evaluate the effects of cropping system management (S1, S2, S3, S5) on WFPS, temperature, mineral nitrogen contents, and $\mathrm{N}_{2} \mathrm{O}$ cumulative emissions. These tests were associated with Dunn paired groups to highlight any significant differences and similarities between the cropping systems. Similarly, the effect of cropping systems on simulated cumulative $\mathrm{N}_{2} \mathrm{O}$ emissions; soil water, nitrogen, and temperature functions; and biological parameters were assessed using Kruskal-Wallis tests with Dunn paired groups.

Linear correlations between both measured and simulated $\mathrm{N}_{2} \mathrm{O}$ emissions and soil WFPS and soil temperatures were assessed using Spearman's rank correlation coefficient. Nonlinear correlations were assessed using generalized additive mixed models. In order to avoid interdependences, smooth functions were employed to describe the relationships between observed $\mathrm{N}_{2} \mathrm{O}$ emissions and predictors.

Association and coincidence criteria between simulated and observed data were used to determine the performance of the models (Smith et al. 1996). A high association meant that the model accurately captured the dynamic data while a high coincidence meant that the model accurately reproduced their range. Spearman's rank coefficient (rho) was used to assess the association between simulated and measured data while the coincidence was assessed with the root mean square error (RMSE) (6), relative root mean square error (rRMSE) (7), and bias error (BE) (8), calculated from the following formulas:

RMSE $=\sqrt{\frac{\sum_{\mathrm{i}=1}^{\mathrm{n}}\left(\mathrm{S}_{\mathrm{i}}-\mathrm{O}_{\mathrm{i}}\right)^{2}}{\mathrm{n}}}$
rRMSE $=\sqrt{\frac{\sum_{\mathrm{i}=1}^{\mathrm{n}}\left(\mathrm{S}_{\mathrm{i}}-\mathrm{O}_{\mathrm{i}}\right)^{2}}{\sum_{\mathrm{i}=1}^{\mathrm{n}}\left(\mathrm{O}_{\mathrm{i}}\right)^{2}}}$

$\mathrm{BE}=\frac{\sum_{\mathrm{i}=1}^{\mathrm{n}}\left(\mathrm{O}_{\mathrm{i}}-\mathrm{S}_{\mathrm{i}}\right)}{\mathrm{n}}$

Additionally, the Nash-Sutcliffe model efficiency coefficient (NSE) was determined to confront cumulative observed $\mathrm{N}_{2} \mathrm{O}$ emissions and $\mathrm{N}_{2} \mathrm{O}$ emissions simulated with the NOE model (9).

$\mathrm{NSE}=1-\left[\frac{\sum_{\mathrm{i}=1}^{\mathrm{n}}\left(O_{i}-S_{i}\right)^{2}}{\sum_{\mathrm{i}=1}^{\mathrm{n}}\left(\mathrm{O}_{\mathrm{i}}-\overline{\mathrm{O}_{\mathrm{i}}}\right)^{2}}\right]$ 
$\mathbf{g ~ N}_{2} \mathbf{O}-\mathbf{N ~ h a}^{-1} \mathbf{d}^{-1} \quad \mathrm{~N}_{2} \mathrm{O}$ emissions observed (line) and simulated with NOE (dot)
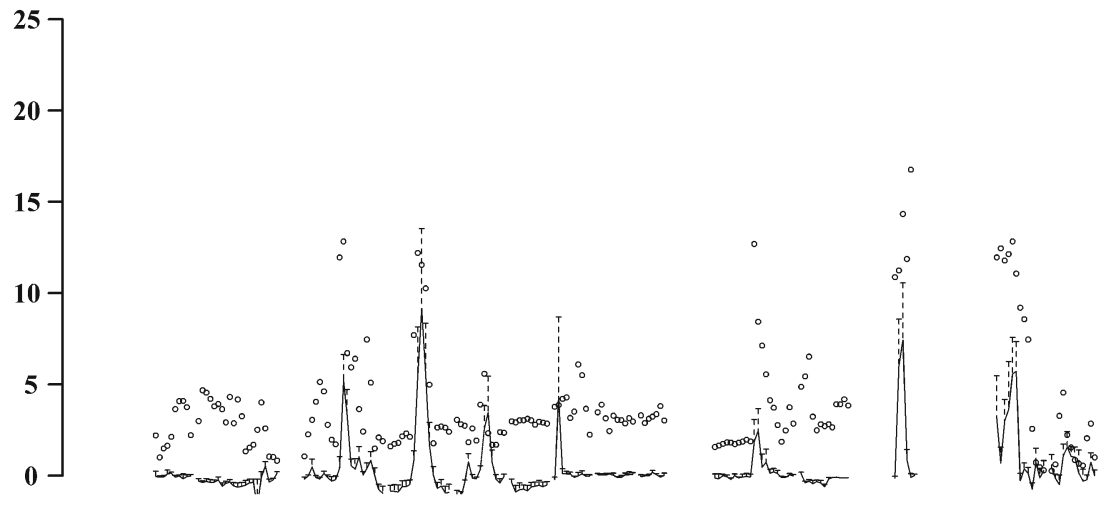

$\left.\begin{array}{l}300 \\ 240- \\ 180- \\ 120- \\ 60- \\ 0\end{array}\right]$
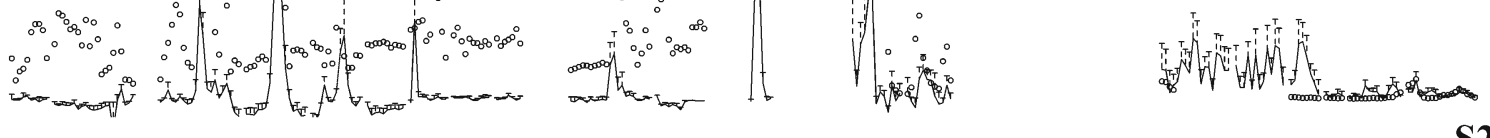

S2
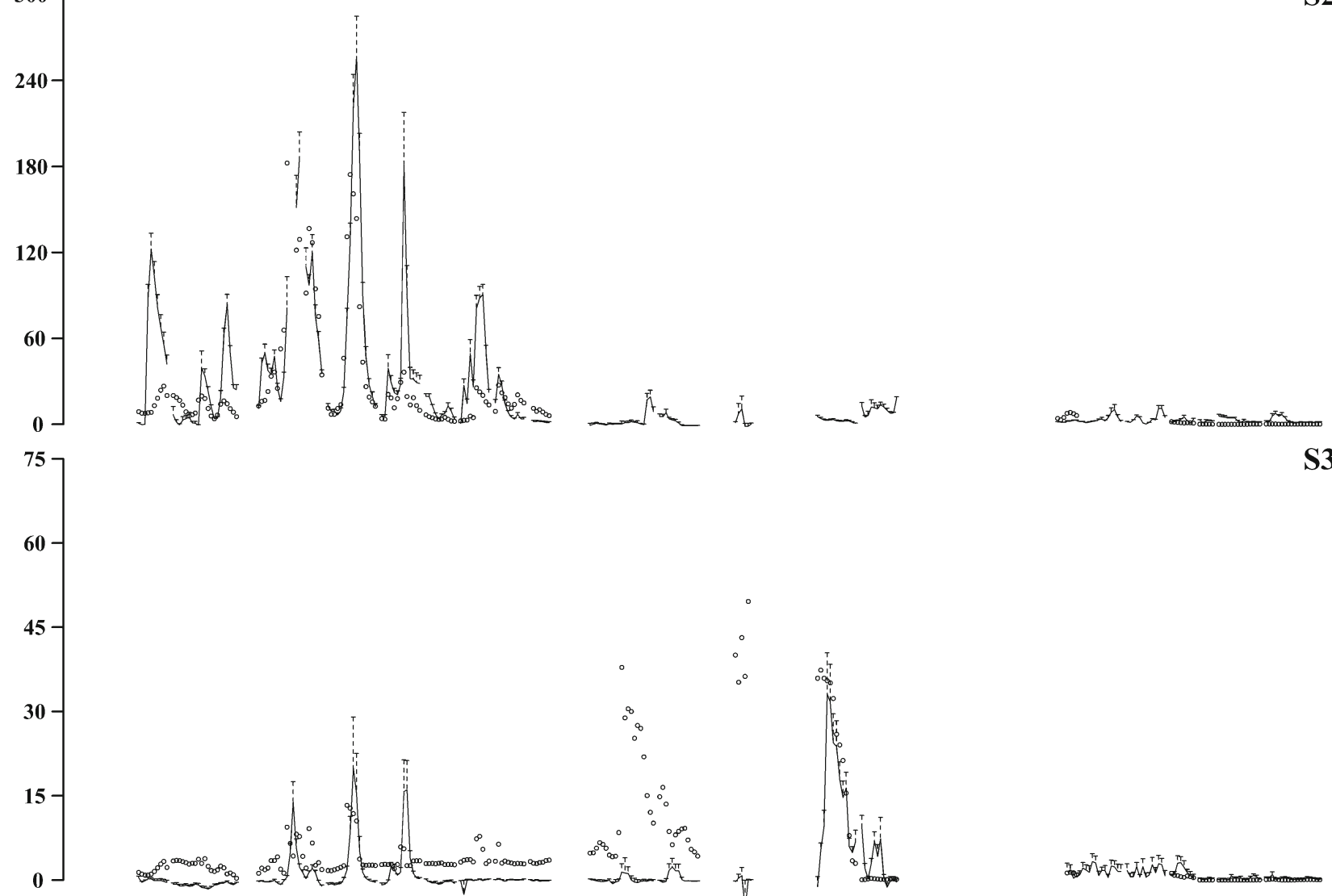

S3
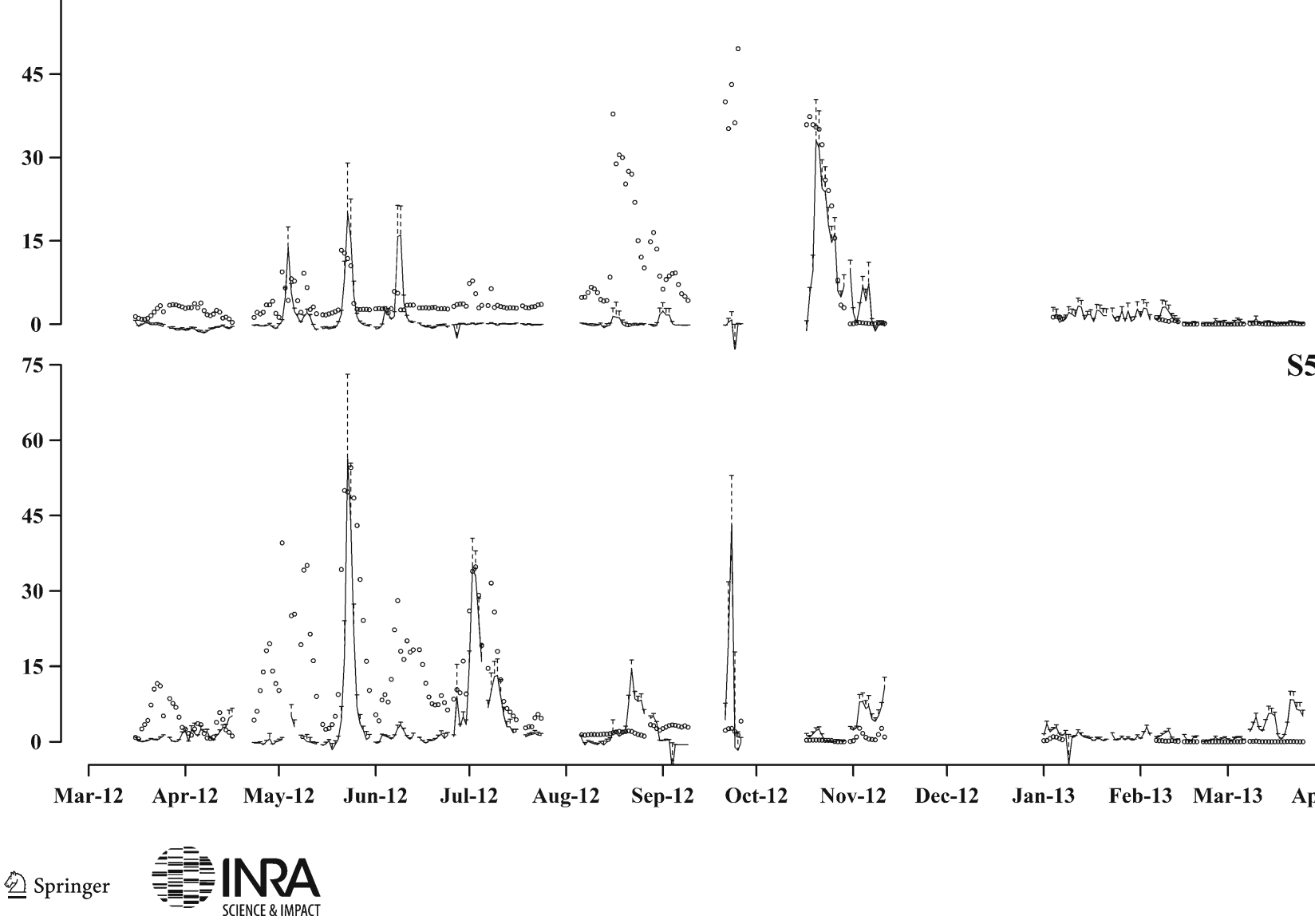

S5 
Fig. 2 Comparison between observed and simulated $\mathrm{N}_{2} \mathrm{O}$ emissions (expressed in $\mathrm{g} \mathrm{N}-\mathrm{N}_{2} \mathrm{O}$ ha $^{-1}$ year $^{-1}$ ) dynamics over 1 year in cropping systems S1 (control), S2 (no tillage), S3 (tillage, half herbicide use), and S5 (zero herbicide). Note that emissions were considerably influenced by cropping systems, with the highest emissions recorded for cropping system S2 (no tillage). Emissions also varied with time: the highest emissions were recorded during spring and after fertilizer applications whereas they were lower for the rest of the year

where $\mathrm{O}$ stands for observed fluxes, $\mathrm{S}$ for simulated fluxes, and $\mathrm{n}$ for the number of observations.

To ensure comparison, comparisons between measured and simulated $\mathrm{N}_{2} \mathrm{O}$ fluxes were performed over the days when both were available, i.e., 163 days.

\section{Results and discussion}

\subsection{Intensity and determinism of observed $\mathrm{N}_{2} \mathrm{O}$ emissions}

High-resolution measurements were performed on all the systems over 1 year, between March 2012 and March 2013, to estimate $\mathrm{N}_{2} \mathrm{O}$ emissions as recommended in the literature (Yao et al. 2009). The specific design used here allowed capturing the high temporal and the spatial variability of the $\mathrm{N}_{2} \mathrm{O}$ emissions inside each plot for all the systems. The limits required by the experimental design (i.e., absence of plants for some periods of measurements, possible modification of soil functioning induced by the presence of chambers) may have modified $\mathrm{N}_{2} \mathrm{O}$ emissions from the soil-plant system. However, the experimental conditions could be considered as comparable between cropping systems, thereby allowing us to compare their emissions; thus, seasonal patterns were identified for the different systems. The emission levels of systems S1, S3, and S5 were globally comparable to those observed in 2011 in the same area (Vermue et al. 2013), as well as to punctual measurements performed in the agricultural region of eastern France (Henault et al. 1998) for comparable pedoclimatic conditions.

Daily $\mathrm{N}_{2} \mathrm{O}$ emissions from the reference system $\mathrm{S} 1$ remained relatively low, ranging from -2 to $9 \mathrm{~g} \mathrm{~N}$ $\mathrm{N}_{2} \mathrm{O}$ ha $^{-1}$ day $^{-1}$ (Fig. 2), with an average flux of $0.5 \mathrm{~g} \mathrm{~N}$ $\mathrm{N}_{2} \mathrm{O}$ ha $^{-1}$ day $^{-1}$. Cumulated emissions were $326 \mathrm{~g} \mathrm{~N}$ $\mathrm{N}_{2} \mathrm{O}$ ha $^{-1}$ over the experimental period for system $\mathrm{S} 1$. For system $\mathrm{S} 3, \mathrm{~N}_{2} \mathrm{O}$ emissions were significantly higher $(p<0.05)$. Daily $\mathrm{N}_{2} \mathrm{O}$ fluxes ranged from -5 to $33 \mathrm{~g} \mathrm{~N}-$ $\mathrm{N}_{2} \mathrm{O}$ ha $^{-1}$ day ${ }^{-1}$ (Fig. 2), with an average daily flux of $1.5 \mathrm{~g}$ $\mathrm{N}-\mathrm{N}_{2} \mathrm{O}$ ha $^{-1}$ day $^{-1}$. The cumulated emissions were $177 \mathrm{~g} \mathrm{~N}-$ $\mathrm{N}_{2} \mathrm{O}^{-1}$ over the year. Despite the absence of $\mathrm{N}$ fertilization, $\mathrm{N}_{2} \mathrm{O}$ emissions from system S5 were significantly higher than those observed for cropping systems S1 and S3 $(p<0.05)$, but nevertheless lower than those observed for the no-till system $\mathrm{S} 2(p<0.05)$. For system $\mathrm{S} 5$, daily $\mathrm{N}_{2} \mathrm{O}$ fluxes ranged between -6 and $56 \mathrm{~g} \mathrm{~N}-\mathrm{N}_{2} \mathrm{O}$ ha $^{-1}$ day $^{-1}$ with an average daily

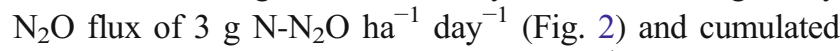
$\mathrm{N}_{2} \mathrm{O}$ emissions reached $777 \mathrm{~g} \mathrm{~N}-\mathrm{N}_{2} \mathrm{O} \mathrm{ha}^{-1}$. The emissions from system $\mathrm{S} 2$ were significantly higher $(p<0.05)$ than all the previous measurements performed in this area, ranging

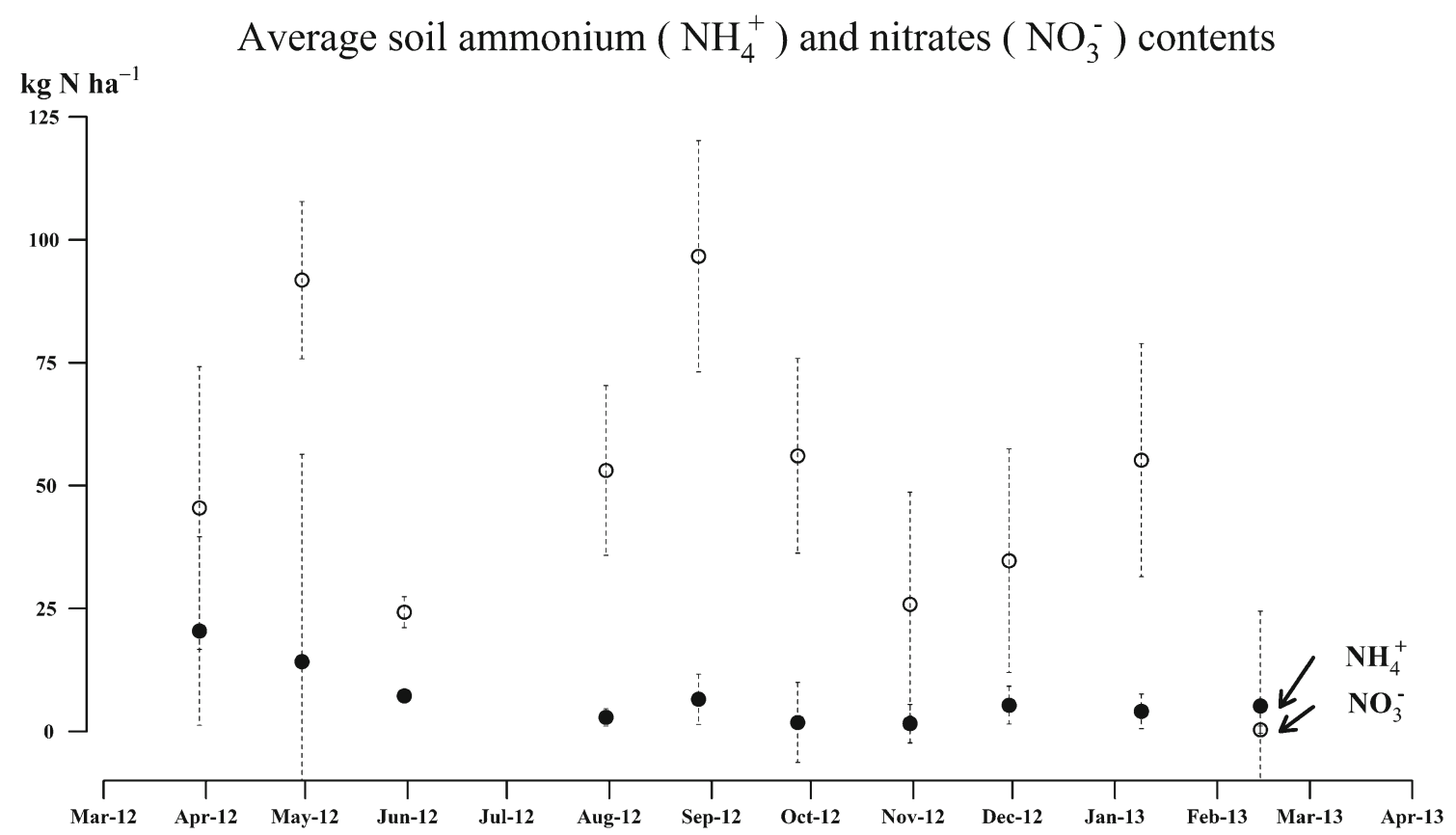

Fig. 3 The evolution of average ammonium and nitrate contents (expressed in $\mathrm{kg} \mathrm{N} \mathrm{ha}^{-1}$ ) in the soils of the experimental site during the study period. Note that soil ammonium contents were very low compared

to soil nitrate contents. Elsewhere, ammonium and nitrate contents were not significantly different between the four systems on each date of measurement 
Table 2 Spearman's coefficients (rho) for the rank correlation between $\mathrm{N}_{2} \mathrm{O}$ emissions simulated with $\mathrm{NOE}$ and functions recording temperature $\left(\mathrm{F}_{\mathrm{T}}\right)$, nitrate $\left(\mathrm{F}_{\mathrm{N}}\right)$, and water $\left(\mathrm{F}_{\mathrm{W}}\right)$ effects, as well as average values observed for soil inorganic N, WFPS, and soil temperature during the study period

\begin{tabular}{|c|c|c|c|c|c|c|c|}
\hline System & $\mathrm{F}_{\mathrm{N}}$ & $\mathrm{N}-\mathrm{NO}_{3}{ }^{-}\left(\mathrm{kg} \mathrm{ha}^{-1}\right)$ & $\mathrm{N}-\mathrm{NH}_{4}{ }^{+}\left(\mathrm{kg} \mathrm{ha}^{-1}\right)$ & $\mathrm{F}_{\mathrm{W}}$ & WFPS (\%) & $\mathrm{F}_{\mathrm{T}}$ & Temperature $\left({ }^{\circ} \mathrm{C}\right)$ \\
\hline S1 & 0.48 & $46 \pm 23$ & $9 \pm 11$ & 0.30 & $64 \pm 4$ & 0.46 & 12.4 \\
\hline S2 & 0.66 & $64 \pm 65$ & $41 \pm 1$ & 0.22 & $68 \pm 3$ & 0.32 & 12.6 \\
\hline S3 & 0.47 & $31 \pm 25$ & $6 \pm 10$ & Not significant & $66 \pm 7$ & 0.42 & 12.4 \\
\hline S5 & 0.14 & $53 \pm 32$ & $4 \pm 3$ & 0.73 & $63 \pm 5$ & 0.44 & 13.0 \\
\hline
\end{tabular}

WFPS water-filled pore space

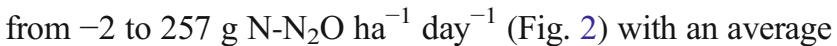

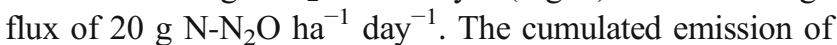
system $\mathrm{S} 2$ was $5226 \mathrm{~g} \mathrm{~N}^{-\mathrm{N}_{2}} \mathrm{O} \mathrm{ha}^{-1}$. Maximum emissions were observed during spring, while the soil emitted an average of $80 \mathrm{~g} \mathrm{~N}^{-\mathrm{N}_{2} \mathrm{O} \mathrm{ha}}{ }^{-1}$ day $^{-1}$ during May 2011, accounting for $40 \%$ of the total $\mathrm{N}_{2} \mathrm{O}$ emitted over the measurement period from this system.

The temporal pattern of $\mathrm{N}_{2} \mathrm{O}$ emissions differed between the systems. $\mathrm{N}_{2} \mathrm{O}$ peaks were observed at about equal levels in spring, summer, and autumn for each of the S1, S3, and S5 systems, while much higher peaks were observed during spring, especially for system $\mathrm{S} 2$ where $71 \%$ of $\mathrm{N}_{2} \mathrm{O}$ emissions were recorded before June 20, 2012. Finally, $\mathrm{N}_{2} \mathrm{O}$ emissions from all the systems remained low most of the time whereas $\mathrm{N}_{2} \mathrm{O}$ was mainly emitted during short peak periods over the year of measurement for all the systems. The lowest $\mathrm{N}_{2} \mathrm{O}$ emissions were observed in winter in all the systems. This can be attributed to lower temperatures, as observed by Laville et al. (2011). Soil temperatures were the factors having the greatest impact on the $\mathrm{N}_{2} \mathrm{O}$ emissions observed. Both nonlinear and linear significant correlations were observed between soil temperature recorded at $-5 \mathrm{~cm}$ and $\mathrm{N}_{2} \mathrm{O}$ emissions in all the systems.

Fertilization periods associated with rainfalls often lead to high $\mathrm{N}_{2} \mathrm{O}$ emissions (Dobbie et al. 1999). In our study, the application of fertilizers in April 2012 in systems S1, S2, and $\mathrm{S} 3$ did not immediately cause $\mathrm{N}_{2} \mathrm{O}$ emission peaks, a phenomenon also reported by Zebarth et al. (2008). However, no significant correlation was established between soil $\mathrm{N}$ dynamics and the $\mathrm{N}_{2} \mathrm{O}$ emissions observed later. Soil $\mathrm{N}$ dynamics were not significantly different between the systems, even including the nonfertilized system S5. High inorganic $\mathrm{N}$ contents were measured in all the systems after the harvesting period in August 2012 (Fig. 3), probably resulting from the mineralization of crop residues and soil organic matter (Velthof et al. 2002). This did not clearly induce $\mathrm{N}_{2} \mathrm{O}$ emissions, whatever the system. Moreover, the emissions of systems S1, S3, and S5 were observed in autumn 2012 despite lower soil inorganic $\mathrm{N}$ contents during this period. Altogether, these observations suggest that soil mineral nitrogen contents were not the main limiting factor for the production of $\mathrm{N}_{2} \mathrm{O}$ during this study.
The $\mathrm{N}_{2} \mathrm{O}$ peaks observed often coincided with high WFPS values while the $\mathrm{N}_{2} \mathrm{O}$ emissions observed were significantly nonlinearly correlated to WFPS $(p<0.05)$ in all the systems and linearly correlated $(p<0.05)$ to systems $\mathrm{S} 1$ (rho $=0.63$ ), $\mathrm{S} 3$ (rho $=0.60)$, and S5 (rho = 0.27). Among the soil processes resulting in $\mathrm{N}_{2} \mathrm{O}$ emissions, nitrification and denitrification are often identified as main contributors to $\mathrm{N}_{2} \mathrm{O}$ emissions under dry and wet soils, respectively, with denitrification producing more $\mathrm{N}_{2} \mathrm{O}$ (Mathieu et al. 2006). This is consistent with the significantly higher WFPS and $\mathrm{N}_{2} \mathrm{O}$ emissions measured for system $\mathrm{S} 2$ and lower soil WFPS and $\mathrm{N}_{2} \mathrm{O}$ emissions measured in $\mathrm{S} 1$ and $\mathrm{S} 3$. This suggests that system $\mathrm{S} 2$ contributed most to the denitrification process while systems S1 and S3 contributed to the nitrification processes.

\subsection{Simulation of $\mathrm{N}_{2} \mathrm{O}$ emissions}

The denitrification potentials used to parametrize NOE appeared to differ between systems, as they were significantly higher for S2 with $4036{\mathrm{~g} \mathrm{~N}-\mathrm{N}_{2} \mathrm{O} \mathrm{ha}}^{-1}$ day $^{-1}$ while they were equal to 1820,1220 , and $1964{\mathrm{~g} \mathrm{~N}-\mathrm{N}_{2} \mathrm{O} \mathrm{ha}}^{-1}$ day $^{-1}$ for systems $\mathrm{S} 1, \mathrm{~S} 3$, and $\mathrm{S} 5$, respectively. Elsewhere, a soil capacity to reduce $\mathrm{N}_{2} \mathrm{O}$ to $\mathrm{N}_{2}$ with $\mathrm{r}_{\max }$ values of $0.69,0.78,0.70$, and 1 was obtained for cropping systems $\mathrm{S} 1, \mathrm{~S} 2, \mathrm{~S} 3$, and S5, respectively. These latter values were used to parametrize NOE.

Simulated emissions ranged between 0 and 17, 182, 50, and $55 \mathrm{~g} \mathrm{~N}-\mathrm{N}_{2} \mathrm{O}$ ha $^{-1}$ day $^{-1}$, for systems S1, S2, S3, and S5, respectively (Fig. 2). In terms of $\mathrm{N}_{2} \mathrm{O}$ emission intensity, the NOE model significantly discriminated and ranked the cropping systems, in the same order as observed. Significantly higher emissions from system S2 were simulated, followed by, in order, systems S5, S3, and S1. According to the observations, nitrification appeared to be the main contributor to $\mathrm{N}_{2} \mathrm{O}$ emissions for system $\mathrm{S} 1$ with $58 \%$ of the emissions. In contrast, a contribution of 68 and $72 \%$ of $\mathrm{N}_{2} \mathrm{O}$ emissions by denitrification was simulated for systems $\mathrm{S} 3$ and $\mathrm{S} 5$. The highest $\mathrm{N}_{2} \mathrm{O}$ emissions by denitrification, with a proportion of $89 \%$, were simulated for system S2, which is consistent with higher WFPS (Table 2) and higher measured $\mathrm{N}_{2} \mathrm{O}$ emissions (Fig. 2). Seasonal patterns were accurately reproduced by the model, especially the high proportion of $\mathrm{N}_{2} \mathrm{O}$ emissions during spring and the low $\mathrm{N}_{2} \mathrm{O}$ emissions 
during winter. As found with the generalized additive mixed modeling of observed $\mathrm{N}_{2} \mathrm{O}$ emissions (detailed results not shown), NOE identified the soil temperature function $\mathrm{Ft}$ as the main factor regulating simulated $\mathrm{N}_{2} \mathrm{O}$ emissions (Table 2). Despite the fact that no significant correlation was observed between measured $\mathrm{N}_{2} \mathrm{O}$ emissions and soil inorganic $\mathrm{N}$ dynamics, as is usually observed in fertilized soils (Zebarth et al. 2008), simulated $\mathrm{N}_{2} \mathrm{O}$ emissions from systems $\mathrm{S} 1, \mathrm{~S} 2$, and S3 appeared to be highly correlated with the response factors for soil nitrate content obtained using the nonlinear Fn function (Table 2). $\mathrm{N}_{2} \mathrm{O}$ emissions from system $\mathrm{S} 5$ simulated by NOE were determined more by the response factor for water contents (Table 2). No similar linear correlation was observed for systems S1, S2, and S3.

The statistical analysis of simulations versus observations revealed that the NOE model accurately reproduced $\mathrm{N}_{2} \mathrm{O}$ emission dynamics and levels for all the cropping systems. The global Nash-Sutcliffe coefficient of efficiency, considering the four cropping systems, was NSE $=0.80$, suggesting better predictions from the model than the estimations from the mean of the $\mathrm{N}_{2} \mathrm{O}$ emissions. Both association and coincidence criteria suggested that the simulation of $\mathrm{N}_{2} \mathrm{O}$ emissions was very accurate. Indeed, simulated and observed $\mathrm{N}_{2} \mathrm{O}$ fluxes were significantly correlated $(p<0.0001)$ for all four systems with rho values of $0.34,0.76,0.43$, and 0.61 for cropping systems S1, S2, S3, and S5, respectively. The RMSE between the observed $\mathrm{N}_{2} \mathrm{O}$ emissions and those simu-

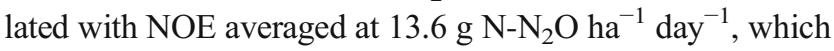
was consistent with previously reported errors. Hergoualc'h et al. (2009) and Gabrielle et al. (2006) reported a maximum

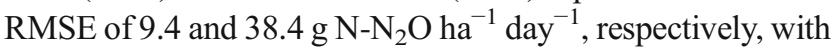
NOE. While NOE could tend to underestimate denitrifying activity related to high WFPS (Gabrielle et al. 2006), we observed an underestimation of the intensity of $\mathrm{N}_{2} \mathrm{O}$ peaks, especially for system $\mathrm{S} 2$, where a maximum $\mathrm{BE}$ and RMSE of 9

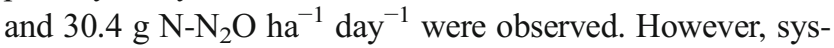
tem $\mathrm{S} 2$ presented the lowest rRMSE, with $0.00 \mathrm{~g} \mathrm{~N}$ $\mathrm{N}_{2} \mathrm{O}$ ha $^{-1}$ day $^{-1}$, while the average rRMSE was $0.10 \mathrm{~g} \mathrm{~N}$ $\mathrm{N}_{2} \mathrm{O}$ ha ${ }^{-1}$ day $^{-1}$. Similarly, the highest Nash-Sutcliffe efficiency coefficient $(\mathrm{NSE}=0.57$ ) was obtained for system $\mathrm{S} 2$. In contrast, our results suggest that NOE tended to overestimate the background nitrification rates for all the cropping systems. From March to December 2012, the model almost continuously simulated low $\mathrm{N}_{2} \mathrm{O}$ emissions $\left(<5 \mathrm{~g} \mathrm{~N}_{2} \mathrm{O}-\mathrm{N}\right.$ ha $\left.{ }^{-1}\right)$ from nitrifying activity. However, while soil temperatures and water and ammonium contents were not limiting for nitrification, significantly lower $\mathrm{N}_{2} \mathrm{O}$ emissions were observed in all the systems. The overestimation was particularly visible for systems $\mathrm{S} 1, \mathrm{~S} 3$, and $\mathrm{S} 5$ which contributed the most nitrification to $\mathrm{N}_{2} \mathrm{O}$ emissions and where BEs of $-3,-5$, and $-4 \mathrm{~g} \mathrm{~N}-$ $\mathrm{N}_{2} \mathrm{O}$ ha $^{-1}$ day $^{-1}$ were observed, respectively. The NashSutcliffe efficiency coefficients were therefore low $(\mathrm{NSE}<0)$ for these systems.
As NOE accurately captured the temporal variability of the emissions, it probably allows accurate characterization of the interactions between the main factors involved in regulating $\mathrm{N}_{2} \mathrm{O}$ emissions. The simulations obtained also discriminated the systems studied well, especially the system with the highest emission. Indeed, NOE identified the no-tillage system $\mathrm{S} 2$ as the most $\mathrm{N}_{2} \mathrm{O}$-emitting system, with a total emission of $3209 \mathrm{~g} \mathrm{~N}-\mathrm{N}_{2} \mathrm{O} \mathrm{ha}^{-1}$ emitted in comparison with the three conventionally tilled systems (S1, S3, and S5). This discrimination was achieved by the system-specific measurement of both the biological and environmental systems, revealing a clearly higher potential denitrification rate of the soil of the S2 system combined with a lightly higher bulk density and thus WFPS.

No-till systems are commonly reported to enhance $\mathrm{N}_{2} \mathrm{O}$ emissions in comparison to conventional systems, especially during the initial years of introduction (Six et al. 2004; Oorts et al. 2007). NOE simulated an average additional emission of $2 \mathrm{~kg} \mathrm{~N}-\mathrm{N}_{2} \mathrm{O} \mathrm{ha}^{-1}$ while an average of $1.95 \mathrm{~kg} \mathrm{~N}^{-\mathrm{N}_{2}} \mathrm{O} \mathrm{ha}{ }^{-1}$ is usually observed over 1 year in temperate soils (Six et al. 2002). Our study therefore confirms the potential for using NOE to estimate the impact of different agricultural practices on $\mathrm{N}_{2} \mathrm{O}$ emissions (Gabrielle et al. 2006). It also reveals that the use of NOE also helps in understanding contrasting levels of $\mathrm{N}_{2} \mathrm{O}$ emissions in different agronomic systems including innovative cropping systems based on integrated weed management.

\section{Conclusions}

Our study contributes to the environmental evaluation of cropping systems that incorporate integrated weed management principles. Thus, our main objective was to compare $\mathrm{N}_{2} \mathrm{O}$ emissions for four cropping systems based on different weed management strategies. We observed a very strong effect of integrated weed management on $\mathrm{N}_{2} \mathrm{O}$ fluxes over a 1year period of investigation in different integrated weed management cropping systems using high-resolution measurements. $\mathrm{N}_{2} \mathrm{O}$ emissions from integrated weed management with no tillage since 2008 (>5000 ${\mathrm{g} \mathrm{N}-\mathrm{N}_{2} \mathrm{O} \mathrm{ha}}^{-1}$ year $^{-1}$ ) were clearly higher than the emissions measured on the other cropping systems with integrated weed management. The NOE model successfully reconstituted patterns of $\mathrm{N}_{2} \mathrm{O}$ emissions, indicating that $\mathrm{N}_{2} \mathrm{O}$ emissions were driven by the interactions between specific potential denitrification rates; bulk densities; and temperature, water, and nitrogen dynamics in soils. Since one of the challenges now facing agriculture is that of mitigating its global warming potential, we have taken a step in this direction by highlighting the reliability of the NOE model as a tool for estimating and understanding $\mathrm{N}_{2} \mathrm{O}$ emissions in the framework of cropping system development and evaluation. 
Acknowledgments This work was funded by the Burgundy Region. We thank A. Coffin for the setup and technical maintenance of the measurement devices, the soil unit of the INRA of Orléans for its help in parameterizing the NOE model, N. Munier-Jolain and the staff of the INRA experimental farm for the field management of the cropping systems, and F. Bizouard for his help in the field experiments.

\section{References}

Chèneby D, Brauman A, Rabary B, Philippot L (2009) Differential responses of nitrate reducer community size, structure, and activity to tillage systems. Appl Environ Microbiol 75:3180-3186. doi:10.1128 /AEM.02338-08

Chikowo R, Faloya V, Petit S, Munier-Jolain NM (2009) Integrated weed management systems allow reduced reliance on herbicides and longterm weed control. Agric Ecosyst Environ 132:237-242. doi:10.1016/j. agee.2009.04.009

Deytieux V, Nemecek T, Freiermuth Knuchel R, Gaillard G, Munier-Jolain NM (2012) Is integrated weed management efficient for reducing environmental impacts of cropping systems? A case study based on life cycle assessment. Eur J Agron 36:55-65. doi:10.1016/j.eja.2011.08.004

Dobbie KE, McTaggart IP, Smith KA (1999) Nitrous oxide emissions from intensive agricultural systems: variations between crops and seasons, key driving variables, and mean emission factors. J Geophys Res 104:26891. doi:10.1029/1999JD900378

Foley JA, Ramankutty N, Brauman KA, et al. (2011) Solutions for a cultivated planet. Nature 478:337-342. doi:10.1038/nature10452

Gabrielle B, Laville P, Hénault C, Nicoullaud B, Germon JC (2006) Simulation of nitrous oxide emissions from wheat-cropped soils using CERES. Nutr Cycl Agroecosyst 74:133-146. doi:10.1007/s10705-0055771-5

Hénault C, Germon JC (2000) NEMIS, a predictive model of denitrification on the field scale. Eur J Soil Sci 51:257-270. doi:10.1046/j.13652389.2000.00314.x

Hénault C, Bizouard F, Laville P, Gabrielle B, Nicoullaud B, Germon JC, Cellier P (2005) Predicting in situ soil $\mathrm{N}_{2} \mathrm{O}$ emission using NOE algorithm and soil database. Glob Chang Biol 11:115-127. doi:10.1111 j.1365-2486.2004.00879.x

Henault C, Cheneby D, Heurlier K, Garrido F, Perez S, Germon JC (2001) Laboratory kinetics of soil denitrification are useful to discriminate soils with potentially high levels of $\mathrm{N}_{2} \mathrm{O}$ emission on the field scale. Agronomie 21:713-723. doi:10.1051/agro:2001165

Henault C, Devis X, Page S, Justes E, Reau R, Germon JC (1998) Nitrous oxide emissions under different soil and land management conditions. Biol Fertil Soils 26:199-207. doi:10.1007/s003740050368

Hénault C, Grossel A, Mary B, Roussel M, Léonard J (2012) Nitrous oxide emission by agricultural soils: a review of spatial and temporal variability for mitigation. Pedosphere 22:426-433. doi:10.1016 /S1002-0160(12)60029-0

Hergoualc'h K, Harmand J-M, Cannavo P, Skiba U, Oliver R, Hénault C (2009) The utility of process-based models for simulating $\mathrm{N}_{2} \mathrm{O}$ emissions from soils: a case study based on Costa Rican coffee plantations. Soil Biol Biochem 41:2343-2355. doi:10.1016/j.soilbio.2009.08.023

IUSS Working Group WRB (2006) World reference base for soil resources 2006 - a framework for international classification, correlation and communication. Food and Agriculture Organization of the United Nations, Rome

Laville P, Lehuger S, Loubet B, Chaumartin F, Cellier P (2011) Effect of management, climate and soil conditions on $\mathrm{N}_{2} \mathrm{O}$ and $\mathrm{NO}$ emissions from an arable crop rotation using high temporal resolution measurements. Agric For Meteorol 151:228-240. doi:10.1016/j. agrformet.2010.10.008

Mathieu O, Hénault C, Lévêque J, Baujard E, Milloux M-J, Andreux F (2006) Quantifying the contribution of nitrification and denitrification to the nitrous oxide flux using ${ }^{15} \mathrm{~N}$ tracers. Environ Pollut 144: 933-940. doi:10.1016/j.envpol.2006.02.005

Oorts K, Merckx R, Grehan E, Labreuche J, Nicolardot B (2007) Determinants of annual fluxes of $\mathrm{CO}_{2}$ and $\mathrm{N}_{2} \mathrm{O}$ in long-term no-tillage and conventional tillage systems in northern France. Soil Tillage Res 95: 133-148. doi:10.1016/j.still.2006.12.002

Pardo G, Riravololona M, Munier-Jolain NM (2010) Using a farming system model to evaluate cropping system prototypes: are labour constraints and economic performances hampering the adoption of integrated Weed Management? Eur J Agron 33:24-32. doi:10.1016/j.eja.2010.02.003

R Core Team (2016) R: a language and environment for statistical computing. R Foundation for Statistical Computing, Vienna, Austria. url: https://www.R-project.org/

Reganold JP, Glover JD, Andrews PK, Hinman HR (2001) Sustainability of three apple production systems. Nature 410:926-930. doi:10.1038 135073574

Rochette $\mathrm{P}$ (2008) No-till only increases $\mathrm{N}_{2} \mathrm{O}$ emissions in poorly-aerated soils. Soil Tillage Res 101:97-100. doi:10.1016/j.still.2008.07.011

Six J, Feller C, Denef K, Ogle SM, de Moraes JC, Albrecht A (2002) Soil organic matter, biota and aggregation in temperate and tropical soils - effects of no-tillage. Agronomie 22:755-775. doi:10.1051 /agro:2002043

Six J, Ogle SM, Breidt FJ, Conant RT, Mosiers AR, Paustian K (2004) The potential to mitigate global warming with no-tillage management is only realized when practised in the long-term. Glob Chang Biol 10:155-160. doi:10.1111/j.1529-8817.2003.00730.x

Smith J, Smith P, Addiscott T (1996) Quantitative methods to evaluate and compare soil organic matter (SOM) models. In: Powlson D, Smith P, Smith J (eds) Evaluation of soil organic matter models. Springer, Berlin Heidelberg, pp. 181-199

Van Groenigen JW, Velthof GL, Oenema O, Van Groenigen KJ, Van Kessel C (2010) Towards an agronomic assessment of $\mathrm{N}_{2} \mathrm{O}$ emissions: a case study for arable crops. Eur J Soil Sci 61:903-913. doi:10.1111/j.13652389.2009.01217.x

Velthof GL, Kuikman PJ, Oenema O (2002) Nitrous oxide emission from soils amended with crop residues. Nutr Cycl Agroecosyst 62:249 261. doi:10.1023/A:1021259107244

Vermue A, Philippot L, Munier-Jolain N, Hénault C, Nicolardot B (2013) Influence of integrated weed management system on $\mathrm{N}$-cycling microbial communities and $\mathrm{N}_{2} \mathrm{O}$ emissions. Plant Soil 373:501-514. doi:10.1007/s11104-013-1821-y

Vilain G, Garnier J, Tallec G, Cellier P (2010) Effect of slope position and land use on nitrous oxide $\left(\mathrm{N}_{2} \mathrm{O}\right)$ emissions (Seine Basin, France). Agric For Meteorol 150:1192-1202. doi:10.1016/j.agrformet.2010.05.004

Weitz AM, Linder E, Frolking S, Crill PM, Keller M (2001) $\mathrm{N}_{2} \mathrm{O}$ emissions from humid tropical agricultural soils: effects of soil moisture, texture and nitrogen availability. Soil Biol Biochem 33:1077-1093. doi:10.1016/S0038-0717(01)00013-X

Yao Z, Zheng X, Xie B, Liu C, Mei B, Dong H, Butterbach-Bahl K, Zhu J (2009) Comparison of manual and automated chambers for field measurements of $\mathrm{N}_{2} \mathrm{O}, \mathrm{CH}_{4}, \mathrm{CO}_{2}$ fluxes from cultivated land. Atmos Environ 43:1888-1896. doi:10.1016/j.atmosenv.2008.12.031

Zebarth BJ, Rochette P, Burton DL (2008) $\mathrm{N}_{2} \mathrm{O}$ emissions from spring barley production as influenced by fertilizer nitrogen rate. Can J Soil Sci 88:197-205. doi:10.4141/CJSS06006

Zoschke A, Quadranti M (2002) Integrated weed management: quo vadis? Weed Biol Manag 2:1-10. doi:10.1046/j.1445-6664.2002.00039.x 